\title{
GIS, Information Technology and Spatial Planning
}

K. Maier

Geographic information systems have been introduced local and regional planning several stages. They have influenced the technique of planning but only to a lesser extent the procedures of planning and the methodology of plan-making. More recently, information technology has challenged the whole concept of planning as an expert-and-government interplay. However, legal frameworks have not reflected the substantial change in the potentials of the technology.

Any effort to reflect the new technology will face not only institutional inertia but increasingly also the human capacity of users of planning (i.e., decision-makers, administrators, stakeholders), namely the limited extent of overall IT literacy, which restricts the possible benefits of the technology. The dimension of access to and empowerment in planning may reappear in the context of new technologies, with new professional requirements for planners, beyond the computer, GIS and information technology.

Keywords: geographical information systems, information technology, spatial planning, participation.

\section{Geographical information systems}

\subsection{What are they?}

Fischer and Nijkamp (ed. 1993) defined a Geographical Information System (GIS) as:

“... a computer-based system for capturing, visualising, checking/validating, storing, manipulating, processing, integrating, analysing and outputting, in map, tabular or $3 D$ formats, spatially referenced data, formed of entities and their associated attributes. A GIS is a toolkit for the modeling and analysis of complex real world problems facing researchers, managers and planners; and a system to support decision makers by enabling them to identify and evaluate potential solutions."

Longley et al (1999) offered another, much briefer definition:

"GIS entails the use of computers to create and depict digital representations of the Earth's surface."

This latter viewing of GIS is less comprehensive and, therefore, much simpler than the other, by Fischer and Nijnkamp. Longley et al restrict their concept to the technology and techniques, leaving out the way in which GIS can be used. This gap between conceptualising GIS as a technology and GIS as a supporting device for decision-making will be followed in this paper. The paper will show how issues in GIS move beyond the technologic a domain toward human and organisational factors and, on a more general level, toward economics and politics.

\subsection{Constraints and limitations}

A gap has been identified between the technology-linked expertise of GIS experts on the one side and, on the other side, the planning and development-based knowledge of the planners and authorities involved in the decision-making processes, who will not aspire to grow beyond the limits of GIS generalists (Godschalk and McMahon 1992: 223). Drummond (1995) noted the emerging gap between GIS as a technological means and the needs of land-use planners, economic developers and other types of city planners; public works engineers, tax assessors, and municipal IS specialists.
Even if the gap is gradually eliminated by the increasing user-friendliness of GIS technology and by improving "GIS literacy" among planners, the application of GIS technology itself proves to be unable to move out of the domain of technical, expert-made planning. The circle of users is strictly limited to the staff of governmental and planning agencies directly linked to the GIS data by means of local networks or CD. Any communication with "the outside world" has to be achieved by non-digital GIS media. Thus the efficiency of the isolated digital GIS itself is low because each piece of information has to be translated from non-digital to digital format (inwards) or from digital to non-digital format (outwards).

As result, the initial fascination with the potential of the technology was later increasingly replaced by the issues of the access and "information economics". Keeping data and, consequently, the relevant information in line with the actual needs of users/clients became the prerequisite for the efficiency of GIS itself. This is more an issue for those who attempt to open the GIS up to the public.

Nedovic-Budic 1999: 285 concluded in their study of the practical effects of GIS technology that: [despite the significant investment of resources in GIS technology] "the most intriguing indication from the research done to date is the lack of substantial benefits in decision making".

\section{Information technologies}

\subsection{Challenge of the internet: improved communication and wider involvement?}

The Internet obviously provides a technology for opening up the digital transfer of data/information: the collection as well as the dissemination of data/information can be done directly, without any transfer to or from non-digital format. Moreover, it enables better provision of information for property owners and residents and for widespread public participation.

This new potential has been discussed by many international authors. According to Drummond (1989), computer information systems can open up technical planning to public scrutiny and input when they are designed to facilitate partici- 
pation. The ease with which GIS can incorporate new parameters and examine additional alternatives, and the power of GIS to illuminate complex concepts and data sets, makes it a very useful tool for public discourse and deliberation.

Carver et al (1998) made a list of ways in which the internet web has been used in a number of cases for public participation: from on-line questionnaire surveys to $3 \mathrm{D}$ virtual reality systems. The potential for more user-friendly information for the public is immense but, as Gill (1999) noted, many of the projects that enable "lay", non-GIS expert participants to query and share their view on development policies were at a relatively early stage of development: "few have developed beyond prototype applications".

The New Charter of Athens proclaimed by the European Council of Town Planners (ECTP) in 1998 described the possibilities of new information technologies as follows:

"[...] information technology increases the possibilities for communication and the diversity of experience. The democratic processes may also be enhanced, by providing information to those who traditionally did not have access to it. Potentially, it can enable the citizen to become involved in the management of the city, provided that there is equitable access to resources.[...] Planning should encourage the optimum use of information technology, with equitable access, so as to obtain the maximum benefits for the citizen."

A careful reading of this at first glimpse, optimistic proclamation, will reveal several restricting conditions. First: information technologies cannot improve communication by themselves. Like any other technology, they are just a means that can bring benefit, or can remain unused or even be misused. Many of those affected by changes lack access to the internet, and even in future not all will have easy access to it or will be able to make use of it. The possibilities of democratisation and enabling participation in the process of planning may also be constrained by other circumstances - starting from the abstract, poorly intelligible slang sometimes used by professionals and ending with attempts to make the data on territory into a goods accessible only by paying the provider for it, ignoring the fact that this data was usually obtained from public sources and/or by using public resources. The mere internet presentation of some fragments of planning data, even if these are the statutory regulations, may not improve communication among administrators, planners and stakeholders: citizens, developers, property owners, etc.

The trend of providing information selectively is another pitfall on the way toward full usage of the technological potentials of ITs. Another myth of technology-initiated change in planning may be born, if we start to believe that information technologies necessarily change the nature of planning. In fact, not much can change if it is only proposals and approved plans that will be displayed for the public. In this case, the change will consist just in more accessible media, but the gain in participation and involvement of "outside" parties will be minimal if any at all. Presentation on the internet can even discriminate against those people who do not have access or are unable to use the internet. Real change can be achieved only by effective demand for information and response to it on the part of governments by making the data a public good.
Pickles (1995) warned that "Opening GIS to the public, e.g. through internet, may raise problems concerning ethical issues and equity". Earlier, Godschalk and Mc Mahon (1992) described the concern in greater in detail: "Some faculty may suspect that computer planning systems can undercut the democratic decision- making process, particularly on issues of social policy involving poor and minority groups. They reason that these groups will not have access to the databases and analytic programs used by government planners to prepare policy recommendations which may affect them. [...] Improperly used, GIS could become a way of shutting out citizens from decision making. On the other hand, it could just as easily have the reverse effect".

Planners may also feel threatened by the general accessibility of data relevant for planning and development. In this way they may lose their "information monopoly". Their activities will be exposed to continuous review by anyone - not only at the moment of a public hearing or ex post, after the plan has been approved.

\subsection{Alternative to statutory plans: interactive, communicative planning?}

An effective combination of GIS and IT can lead to a redefinition of the requirements for statutory planning. Instead of the existing focus on fixed, periodically reviewed and re-elaborated plans as collections of controls and regulations for the use of land, the dominant value for decision-making would consist in constantly upgraded sets of relevant information on the potentials for and the impact of prospective development. It can be believed, in line with the arguments of Habermas (e.g., 1985,1987) that, however contradictory the particular interests of stakeholders may be, the individual decisions are mostly of a rational nature, and this is the "communicative rationality" that helps to reach a consensus. Therefore the improved quality of information provided concerning the consequences of a prospective development may clarify the points and, in this way, improve communication among the stakeholders.

Following this argument, the technology of GIS combined with effective IT-supported communication, will lead to rationality and flexibility of planning in the face of the increasingly changing environment of planning. If there is a system of permanent data collection and updating, the continuous evaluation of the changing data, flexible adjustment of controls and regulations can speed up the "survey plan - implementation - feedback" cycle and can consequently, replace - at least partly - the traditional rigid plans. The scope of the controls may not be so broad as is usual in contemporary practice, being to a significant extent replaced by relevant and reliable information. The "hard" limits and regulations presented by statutory controls can be to a significant extent replaced by "soft" information of the GIS-based data, interpretated and disseminated by IT.

\section{Specifics of planning-oriented GIS}

By their nature, planning-oriented GIS-based Spatial Decision-Support Systems (SDSSs) address only a selected population of planners, investors and developers. However they can be accessed openly, without any restrictions, their information value being limited to the level of GIS data that does not provide data attached to particular plots/parcels. In 
this way their value for individuals is lower; in fact in this way they avoid the threat of "trivialisation of planning decisions" leading to "nintendo decision-making" (Carver and Peckham: 387).

In fact, the central objective of the public presentation of nation-wide comprehensive GIS does not focus on participation but rather on transparency and equal access to data. The importance of feedback is low from the viewpoint of citizens while from the viewpoint of the authorities it will be legally enforced in the "duty to inform".

Even if not focused on participation, nation-wide SDSS transmitted by internet is another level of the opening-up of planning. Three levels can be identified in the recent history of Czech planning in this respect:

1) The authoritarian model was applied in planning practice before 1989. There was a monopoly on data as well as information; it was the state bureaucracy that decided which data would be provided and also which information would be distributed. The decision-making was also mostly controlled by the state, leaving just a minor role for individuals.

2) The "enlightenment" model of open information was introduced with the liberalisation of the 1990s. Data originating within the public domain is defined by law as public. There is no monopoly on converting it into information, but in the case of geographical data for planning, access is restricted by physical constraints: the resources of relevant data are dispersed, and therefore it is only professional planners that can develop relevant information by collecting and interpreting the data.

3) The forthcoming SDSS model relevant to the information age opens access to GIS-based data for all citizens. This provides an opportinity to transform the data individually and tailor-made into information. This opportunity can obviously be used best by those professionally involved in the investment and development process, while other stakeholders will have to rely on professional interpretations offered by planners. Better and more "independent" information will thus improve, above all the quality of the decisions made by "professional" stakeholders. Information disseminated by the internet will, however, also improve the quality of individual decisions made by small property owners and residents, on a very basic level, through "voting with their feet".

This hypotheses is similar to the "enlightenment" scenario of Carver and Peckham (1999:389), which also does not anticipate that "the responsibilities of strategic planning decisions will, without doubt, remain firmly with the professional and trained planners, managers, government ministers and politicians".

\section{Constraints of multi-user, web-communicated SDSS}

While SDSS designated for a predefined group of users can be tailor-made for legitimate users, the starting position is much less clear when on-line GIS information about the SDSS is to be provided for a broader range of diverse, undefined users.
When designing a GIS as information to be made available to the general public, several areas of constraints have to be considered.

\subsection{Technological considerations}

Internet presentation limits the users to those who have access to the internet. In this way, the first level of exclusion is executed. Among the remaining potential users, the level of technological equipment is very varied. It is essential that - in order not to exclude potential users - the requirements of the presentation should fit with the most basic quality of hardware and internet links that can be expected among the users. On the other hand, if the presentation is adjusted to the poorest anticipated equipment, the resulting quality will hardly be satisfactory for more frequent and obviously much better equipped users, e.g., professional planners.

To ensure that as many users as possible may benefit from on-line access to GIS information, the internet presentation will have to manage only with software that is generally available, i.e., freeware. Any requirement for additional software is a barrier for occasional users, who will probably not buy such software just a single piece of information. However, a presentation that uses only freeware tools may not be satisfactory for everyday professional users, whose requirements for, e.g., a combination of particular elements of the GIS and links between the geographic data and other databases, cannot be successfully met by standard freeware.

Two different approaches can be adopted to solve the apparent dilemma between excellence and affordability:

- A compromise is sought between the desired quality and the range of users. This requires reasonably good information on the range of hardware and linkage in general use. With this data available, the optimisation can take into account the number of users or, rather the number of cases of use. Some optimism is fully legitimate, as innovation in computer hardware and software is very rapid. This same consideration, however means, that any research is soon out-of-date. This makes any optimisation a guess rather, than a solid basis for decision making.

- The presentation is split into two qualitative grades: (a) the basic grade, available for all, as simple as possible in terms of technical requirements for the technology, and (b) the "advanced" for frequent users which assumes certain level of equipment and may also require for some special software on the part of the user.

In the long run, the constraints of technology will tend to diminish. Therefore, the basic standard of presentation may become high enough to meet the requirements of GIS presentation on a equipment. This consideration, however, may prove to be false, as there may be a group of users of very old equipment, as in the case for cars.

\subsection{Human capacity}

Human capacity and technical considerations coincide and overlap considerably. There are diverse potential users, from occasional, one-time users to professionals who need GIS information every day as a part of their business. The public presentation should be as user-friendly as possible, in order not to discourage the occasional users, who may not be quite well informed about the kind of service that of internet 
GIS offers. Also the capability of one-time users to operate the internet presentation will be limited, and this again is a reason for rather simple architecture to avoid deadlocks caused by less competent user.

Frequent users will have no problems with operating the presentation, but they will require the presentation to enable special adjustments to their specific needs. Lengthy introductory information about how to operate the presentation will frustrate them, if they are not able to skip these procedures.

The ways of dealing with the diverse human capacity of users are similar to those for diverse technology.

- The compromise approach consists in stratified architecture of the presentation that will enable a user to operate the presentation on different levels of "internet skills". It is essential that instructions and advice provided to the users should be tested on different persons with different skills in order to avoid gaps in the instructions, where professional slang is used instead of generally comprehensible language. The more complicated tasks should be in a higher layer, in order not to disturb the unskilled user.

- If the approach of two grades of quality is accepted, the advanced, more complicated level of instructions can form a part of the "advanced" grade of the presentation. Even the "advanced" level should be stratified, because unskilled users also use high-level technology.

Unlike the technology, the human capacity cannot be expected to improve much even in the long run. Userfriendliness will remain an important issue, not only for less-skilled users (increasingly as computer and IT literacy will be essential for almost all population) but also for those for whom seeking information on the internet and work in a GIS environment is their everyday business.

\subsection{Organisational and institutional constraints}

Public access to data from the public sector is a legal right for citizens in most democracies, with the exception of secret information that is protected by law. On the other hand, some data was originally collected and information based on it was created outside the domain of the public sector. It is doubtful whether public resources can cover the costs for procuring and continuously upgrading the whole range of data needed for spatial planning and development. Moreover, if all this data is provided by the state, regional or local government to an unlimited general public, it will undoubtedly also be used commercially, e.g. for printing maps, by the private sector.

The current Czech practice in this respect is confused. While the author's rights are covered by the Intellectual Property Law (2000), the very principle of authorship in the case of GIS data is difficult to follow precisely. Others can change the data set created by someone incrementally, which makes the rights and responsibilities unclear. Moreover, with the privatisation in the 1990s of many organisations that collect and create GIS data, it is unclear whether the data sets are public property, especially if they were originally created with public funding but, since privatisation, they have been maintained and updated by a private company.

\section{User-determined alternatives of SDSS}

The following table shows the impact of the designated users to whom information from GIS is distributed on the technology, media of delivery and organisation of data collection.

\begin{tabular}{|c|c|c|c|c|}
\hline $\begin{array}{c}\text { Designated (range of) } \\
\text { users }\end{array}$ & $\begin{array}{l}\text { Use to which the GIS product } \\
\text { has to be oriented }\end{array}$ & $\begin{array}{c}\text { Critical element } \\
\text { of technology for which the } \\
\text { GIS product } \\
\text { has to be adjusted }\end{array}$ & $\begin{array}{c}\text { Media for } \\
\text { channelling the } \\
\text { GIS data to the } \\
\text { user }\end{array}$ & $\begin{array}{l}\text { Critical organisational } \\
\text { element in data } \\
\text { collection and } \\
\text { management }\end{array}$ \\
\hline $\begin{array}{l}\text { plan-makers, } \\
\text { planning department }\end{array}$ & $\begin{array}{c}\text { plan-making: map and report pro- } \\
\text { posals to be submitted } \\
\text { to decision-makers }\end{array}$ & $\begin{array}{l}\text { quality of hardware in the } \\
\text { planning office }\end{array}$ & $\begin{array}{l}\text { plotter and paper } \\
\text { drawings \& reports }\end{array}$ & $\begin{array}{l}\text { availability of } \\
\text { up-to-date data at the } \\
\text { time of plan-making }\end{array}$ \\
\hline $\begin{array}{l}\text { administration (plan- } \\
\text { ning \& other related) } \\
\text { + decision-making } \\
\text { in planning }\end{array}$ & $\begin{array}{l}\text { a) operative decision-making of ad- } \\
\text { ministrators (planning permission) } \\
\text { b) strategic decisions }\end{array}$ & $\begin{array}{l}\text { server of local } \\
\text { network; } \\
\text { capacity of the network; } \\
\text { software used }\end{array}$ & $\begin{array}{l}\mathrm{CD} ; \\
\text { on-line access by } \\
\text { local networks } \\
\text { or intranet }\end{array}$ & $\begin{array}{l}\text { availability of } \\
\text { up-to-date } \\
\text { data at the time } \\
\text { of decision-making }\end{array}$ \\
\hline $\begin{array}{l}\text { important } \\
\text { stakeholders: } \\
\text { investors, developers }\end{array}$ & $\begin{array}{l}\text { information on limits, regulations } \\
\text { and potentials for development; } \\
\text { information on proposed public in- } \\
\text { vestment and other major projects }\end{array}$ & $\begin{array}{l}\text { capacity of the } \\
\text { transmitting network; } \\
\text { software and hardware } \\
\text { of users }\end{array}$ & $\begin{array}{l}\mathrm{CD} ; \\
\text { (paid) access } \\
\text { through internet \& } \\
\text { special software }\end{array}$ & \multirow{3}{*}{$\begin{array}{l}\text { continuously } \\
\text { updated data }\end{array}$} \\
\hline $\begin{array}{l}\text { citizens, } \\
\text { property owners in } \\
\text { general: } \\
\text { general internet users }\end{array}$ & $\begin{array}{l}\text { information on property } \\
\text { values, } \\
\text { proposed public and other projects }\end{array}$ & $\begin{array}{l}\text { capacity of the } \\
\text { transmitting network; us- } \\
\text { ers' accessing devices and } \\
\text { hardware }\end{array}$ & $\begin{array}{l}\text { internet without } \\
\text { any restrictions }\end{array}$ & \\
\hline all citizens & proposed public and other projects & $\begin{array}{l}\text { none } \\
\text { (computer-based IT is not } \\
\text { available for all } \\
\text { citizens) }\end{array}$ & $\begin{array}{l}\text { generally accessi- } \\
\text { ble media: } \\
\text { TV, newspapers + } \\
\text { leaflets } \\
\text { distributed to } \\
\text { households; } \\
\text { internet } \\
\text { in future }\end{array}$ & \\
\hline
\end{tabular}


Note that while the technology requirements on the part of GIS information providers are virtually the same in the all cases, the costs of media to channel the GIS data to users decrease as the range of users increases, and the organisational costs for the data maintenance and updating soar when their use changes from one-time periodically reviewed plans to everyday operational support for decision-making.

The costs expended for permanently collected and updated databases are becoming central issue as soon as the application moves from occasional, periodical reviews towards continuous support for decision-making. As the other costs are not immediately related in a significant way to the range of designated users or the purposes for which they use the GIS data and information, costs cannot be saved by restricting access to GIS. Consequently, as long as the GIS data is considered to be a public good, its widespread availability will be the most economical way. In other words, establishing and running up-to-date GIS can be efficient and economically justified only by widespread access and use. The economics of GIS within the public domain and its accessibility are therefore intertwined.

On the other hand, if GIS data were a private goods, efficiency would involve optimising (a) the quality of the information provided by the GIS data (e.g. whether the data is up-to-date) and (b) the number of users/clients and the users that they implement.

The model for providing GIS data can combine both concepts. Here, the basic range of GIS data will be treated as a public good, with widespread dissemination and unlimited access. Additionally, specific data originating outside the public domain as well as ad-hoc information and evaluations compiled from publicly accessible data can be provided to customers on a commercial basis. It is beyond the scope of this paper to discuss whether the commercial use of public GIS databases could be charged for and if so, which criteria should be used.

Responsibility for the quality of the data rests with the manager. Thus the state, regional and/or local governments will have to guarantee the quality of public GIS data, and responsibility for data and information offered on the market will be a matter of business law.

It is for the politicians to specify what the public domain in GIS data is, and to take responsibility for it. In the political arena, economic criteria are just one component for decisions. In a democracy it is the public choice which is dominant for political decision making. This makes the issue of public GIS extremely fragile: the general public is being offered something unfamiliar, of unclear use and probably with benefits that are not evenly spread.

As open access to GIS data and information breaks into some established monopolies on information, the very idea may not find many serious advocates. Planners will be among those who lose their privileged access to good information. The position of private developers will be ambivalent: they will benefit from easy and free access to basic data, but at the same time they may also be exposed to the improved competence and intelligence of their "lay" counterparts, i.e. individual property owners. The major potential benefit will be to civic society. Therefore, successfully introduced and well run public GIS data provided to everyone for free can be some kind of indicator of how strong civic society is compared to the bureaucracy and the business and professional lobbies.

\section{The content of publicly presented GIS data, and level of participation}

In the next step of analysis of the use of GIS data, the famous ladder of public participation by Arnstein (1969) will be used to illuminate the relations between how and for what the GIS database is provided for the public, and what the level of participation is.

\begin{tabular}{|l|c|}
\hline \multicolumn{1}{|c|}{$\begin{array}{c}\text { Content and way of use } \\
\text { of publicly accessed GIS data }\end{array}$} & $\begin{array}{c}\text { "Rung" level } \\
\text { of participation }\end{array}$ \\
\hline $\begin{array}{l}\text { reversed flow of data and information - } \\
\text { introducing initiative projects in GIS }\end{array}$ & citizen control \\
\hline $\begin{array}{l}\text { balanced two-way flow of data and informa- } \\
\text { tion between authority and public - interac- } \\
\text { tive modules seeking for citizens' opinion } \\
\text { on the presented projects and/or alternative } \\
\text { proposals; opinion polls to identify } \\
\text { local/regional problems and seeking advice } \\
\text { on how to tackle them }\end{array}$ & partnership \\
\hline $\begin{array}{l}\text { continuous and unconstrained flow of data } \\
\text { and information from authority to } \\
\text { public - drafts and proposals for all projects } \\
\text { before they are discussed at public hearings; } \\
\text { allowing feedback comments from webpage } \\
\text { visitors }\end{array}$ & consultation \\
\hline $\begin{array}{l}\text { "soft" data for development - evaluation of } \\
\text { potentials for development, property maps }\end{array}$ & informing \\
\hline $\begin{array}{l}\text { "hard" data for development - statutory } \\
\text { limits for development: e.g. protected } \\
\text { zones, nature reservations and parks, } \\
\text { water resource protection... }\end{array}$ & non-participation \\
\hline
\end{tabular}

Our real-life experience hardly extends beyond the "rung"/level of consultation, so the imagination of an appropriate IT-accessed GIS...

\section{Key data sources}

- GIS Territorial Planning Data - Czech Republic, 2000; internet presentation on http://www.utpcr.cz

- Master Plan for Prague, 1999; internet presentation on http://www.prague-city.cz/

- Strategic Plan for Prague, 2000; internet presentation on http://www.prague-city.cz/

- some other Czech local and regional plans can be found on http://www.egis.cz/VUC/

\section{References}

[1] Action Plan of State Information Policy - Czech Republic, 2000.

[2] Arnstein, S. R.: A Ladder of Citizen Participation. In: Journal of the American Institute of Planners 8, 1969.

[3] Intellectual Property Law 2000 (Zákon o právu autorském ... (autorský zákon) 121/2000) - Czech Republic. 
[4] Carver, S., Kingston, R., Turton, I.: Review of Graphical Environments on the World Wide Web as a Means of Widening Public Participation in Social Science Research. Report for Advisory Group on Computer Graphics. 1998.

[5] Carver, S., Peckham, R.: Using GIS on the Intermet for Planning. 1999.

[6] Drummond, W. J.: The Design of Information System for Public Issues: An Impact Fee Prototype Study. Department of City and Regional Planning, University of North Carolina at Chapel Hill, 1989.

[7] Drummond, W. J.: Extending the Revolution: Teaching Land Use Planning in a GIS Environment. In: Journal of Planning Education and Research, Vol. 14, 1995, p. 280-291.

[8] ECTP (European Council of Town Planners): New Charter of Athens, 1998, available on http://www.ceu-ectp.org.

[9] Fischer, M., Nijkamp, P. (ed): GIS, Spatial Modelling and Policy Evaluation. Berlin: Springer, 1993.

[10] Gill, M.: Public Participation and the Development Plan: AS GIS Approach. In: Innovations in GIS 6, London: Taylor and Francis, 1999.

[11] Gill, S., Higgs, G., Nevitt P.: GIS in Planning Departments: Preliminary Results from a Survey of Local Planning in Wales. In Planning Practice and Research, Vol. 14, No. 3, 1999, p. 341-361.

[12] Godschalk, D. R., McMahon G.: Staffing the Revolution: GIS Education for Planners. In Journal of Planning Education and Research, Vol. 11, 1992, p. 216-226.

[13] Habermas, J.: Questions and Counterquestions: Habermas and Modernity. Cambridge MA: MIT Press, 1985.

[14] Habermas, J.: Philosophical Discourse of Modernity. Cambridge MA: MIT Press, 1987.

[15] Heikkila, E. J.: GIS is Dead: Long Live GIS! In: Journal of the American Planning Association, Vol. 64, No. 3, 1998, p. 350-360.

[16] Higgins, M., Morgan, J.: The Role of Creativity in Planning. In: Planning Practice and Research, Vol. 15, No. 1/2, 2000, p. 117-127.
[17] Higgins, M., Morgan, J.: The Role of Creativity in Planning: The "Creative Practitioner". In: Planning Practice and Research, Vol. 15, No. 1/2, 2000, p. 117-127.

[18] Klostermann, R. E.: Planning Support Systems: A New Perspective on Computer-Aided Planning. In Journal of Planning Education and Research, Vol. 17, 1997, p. 45-54.

[19] Longley, P. A., Goodchild M. G., Maguire, D. J., Rhind, D. W.: Geographical Information Systems: Principles, Techniques, Management, Applications. Geo-information International, Cambridge, 1999.

[20] Maier, K.: Czech Planning in Transition: Assets and Deficiencies. In: International Planning Studies, Vol. 3, No. 3, 1998.

[21] Nedovic-Budic, Z.: Evaluating the Effects of GIS Technology: Review of Methods. In: Journal of Planning Literature, 1999.

[22] New Charter of Athens 1998. European Council of Town Planners.

[23] Pickles, J.: Ground Truth: The Social Implications of Geographic Information Systems. London: The Guildford Press, 1995.

[24] Planning and Building Law - Czech Republic - 2000 Bill, approved by the Czech government in June 2000.

[25] Planning By-Law 2001 (Vyhláška o územně plánovacích podkladech a územně plánovací dokumentaci 135/2001) - Czech Republic.

[26] Vorel J.: The Czech National GIS Database System. Student paper at KTH Stockholm, 2001.

Prof. Ing. arch. Karel Maier, CSc.

phone: +420224354896 +420224354981

e-mail:maier@fa.cvut.cz

Czech Technical University in Prague

Faculty of Architecture

Thákurova 7

16634 Prague 6, Czech Republic 